The meteorological record for the week ending February 28 th, in Boston, was as follows, according to observations furnished by Sergeant O. B. Cole, of the United States Signal Corps:-

\begin{tabular}{|c|c|c|c|c|c|c|c|c|c|c|c|c|c|c|c|c|c|c|c|}
\hline \multirow[b]{2}{*}{$\begin{array}{c}\text { Date. } \\
\text { February, } \\
1885\end{array}$} & \multirow{2}{*}{ 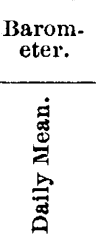 } & \multicolumn{3}{|c|}{ Thermometer. } & \multicolumn{4}{|c|}{$\begin{array}{c}\text { Relative } \\
\text { Humldity. }\end{array}$} & \multicolumn{3}{|c|}{$\begin{array}{l}\text { Direction of } \\
\text { Wind. }\end{array}$} & \multicolumn{3}{|c|}{$\begin{array}{l}\text { Velocity of } \\
\text { Wind. }\end{array}$} & \multicolumn{3}{|c|}{$\begin{array}{l}\text { State of } \\
\text { Weather. }\end{array}$} & \multicolumn{2}{|c|}{ Rainfall. } \\
\hline & & 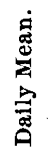 & 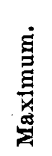 & 鸹 & $\underset{\dot{a}}{\dot{\alpha}}$ & $\begin{array}{l}\dot{x} \\
\dot{x} \\
\text { की } \\
\text { की }\end{array}$ & 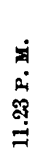 & 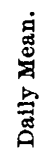 & 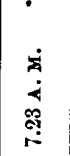 & 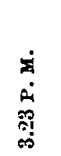 & 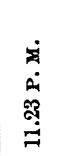 & 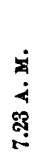 & $\begin{array}{l}\dot{2} \\
\dot{n} \\
\ddot{\alpha}\end{array}$ & 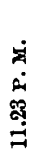 & \begin{tabular}{l}
$\dot{2}$ \\
$\dot{4}$ \\
\multirow{2}{*}{}
\end{tabular} & $\begin{array}{l}\dot{z} \\
\dot{m} \\
\dot{\alpha} \\
\dot{m}\end{array}$ & 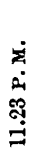 & 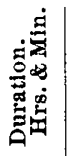 & 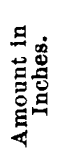 \\
\hline $\begin{array}{ll}\text { Sunday, } & 22 \\
\text { Monday, } 23 \\
\text { Tuesday, } 24 \\
\text { Wednes., } 25 \\
\text { Thurs., } 26 \\
\text { Friday, } 27 \\
\text { Saturday, } 28\end{array}$ & $\begin{array}{l}30.026 \\
30.199 \\
30.312 \\
30.110 \\
30.119 \\
29.965 \\
30.039\end{array}$ & $\begin{array}{l}22.3 \\
19.6 \\
24.1 \\
25.7 \\
26.7 \\
32.1 \\
35.2\end{array}$ & $\begin{array}{l}28.0 \\
26.0 \\
33.0 \\
31.0 \\
32.1 \\
34.2 \\
42.2\end{array}$ & $\begin{array}{l}14.0 \\
14.9 \\
11.4 \\
22.5 \\
16.7 \\
28.3 \\
28.0\end{array}$ & $\begin{array}{r}75 \\
63 \\
63 \\
100 \\
68 \\
69 \\
75\end{array}$ & $\begin{array}{l}68 \\
49 \\
62 \\
59 \\
65 \\
67 \\
49\end{array}$ & $\begin{array}{l}73 \\
67 \\
51 \\
73 \\
73 \\
67 \\
64\end{array}$ & $\begin{array}{l}68.7 \\
59.7 \\
58.7 \\
77.3 \\
68.7 \\
67.9 \\
62.7\end{array}$ & $\begin{array}{c}\mathbf{W} \\
\mathbf{W} \\
\mathbf{W} \\
\mathbf{S} \mathbf{W} \\
\mathbf{N} \mathbf{W} \\
\mathbf{N} \mathbf{E} \\
\mathbf{N} \mathbf{W}\end{array}$ & $\begin{array}{l}\mathbf{W} \\
\mathbf{N} W \\
\mathbf{W} \\
\mathbf{N} \\
\mathbf{E} \\
\mathbf{N} \\
\mathbf{W}\end{array}$ & $\begin{array}{l}\mathbf{N} \mathbf{W} \\
\mathbf{N} \mathbf{W} \\
\mathbf{W} \\
\mathbf{N} \\
\mathbf{S} \mathbf{E} \\
\mathbf{N} \\
\mathbf{S} \mathbf{W}\end{array}$ & $\begin{array}{r}12 \\
14 \\
11 \\
7 \\
7 \\
5 \\
4\end{array}$ & $\begin{array}{r}12 \\
12 \\
8 \\
12 \\
6 \\
6 \\
12 \\
8\end{array}$ & $\begin{array}{r}18 \\
19 \\
12 \\
8 \\
2 \\
2 \\
3 \\
4\end{array}$ & $\begin{array}{c}\mathbf{C} \\
\mathbf{C} \\
\mathbf{C} \\
\text { Snow } \\
\mathbf{C} \\
\mathbf{O} \\
\mathbf{H}\end{array}$ & $\begin{array}{l}\mathbf{O} \\
\mathbf{C} \\
\mathbf{F} \\
\mathbf{C} \\
\mathbf{C} \\
\mathbf{F} \\
\mathbf{F}\end{array}$ & $\begin{array}{l}\mathbf{O} \\
\mathbf{C} \\
\mathbf{O} \\
\mathbf{C} \\
\mathrm{O} \\
\mathrm{O} \\
\mathbf{C}\end{array}$ & $\begin{array}{l}\bar{z} \\
\bar{z} \\
\bar{z}\end{array}$ & $\begin{array}{l}\bar{z} \\
\bar{z} \\
\overline{-}\end{array}$ \\
\hline $\begin{array}{l}\text { Mean, the } \\
\text { Week. }\end{array}$ & 30.110 & 26.5 & 32.3 & 19.4 & & & & 66.2 & & & & & & & & & & 6.00 & 0.04 \\
\hline
\end{tabular}

1 O., cloudy; C., clear; F., fair; G., fog; H., hazy; S., smoky; R., rain; T., threatening.

OFFICIAL LIST OF CHANGES IN THE STATIONS AND DUTIES OF OFFICERS SERVING IN THE MEDICAL DEPARTMENT, U. S. ARMY, FROM FEBRUARY 28,1885 , TO MARCH 6,1885 .

Byrne, Charles C., major and surgeon. Ordered to Department of the East on expiration of his present leave of absence. S. O. 50, A. G. O., March 3, 1885 .

WOODRUFF, EzRA, captain and assistant surgeon. Ordered for duty at Fort Maginnis, Mont. T. S. O. 23, Department of Dakota, February 25, 1885.

EwING, C. B., first lieutenant and assistant surgeon. Having relinquished unfinished portion of leave of absence, ordered for temporary duty in the field. S. O. 29, Department of Missouri, March 2, 1885 .

RAYMOND, HENRY I., first lieutenant and assistant surgeon (recently appointed). Ordered for duty in Department of California. S. O. 50, A. G. O., March 3, 1885.

\section{THE LATE SAMUEL A. FISK, M.D.}

Resolutions upon the death of Dr. Samuel A. Fisk, of Northampton, adopted by the Hampshire District Medical Society:-

Whereas, This Society, having recently lost by death one of its oldest and most honored members, who has held the offices of trust of the local Society, and that of President of the parent Society, we deem it just and fitting that official notice be taken of the departure of our esteemed associate. Therefore

Resolved, That in the decease of our most respected brother, Dr. Samuel A. Fisk, we mourn the loss of a colleague of high intellectual qualities, of broad and general culture, a skilful physician and surgeon, whose heart was always in his work, of steadfast loyalty to the profession and unfeigned fidelity to his patients, an honored citizen, and a cordial friend in all the relations of life.

Resolved, That we hold him in pleasant remembrance as one who was an ornament and an honor to the profession to which he was devoted, and was so earnest to uphold, strengthen, and make subservient to the best interests of his fellow-men, as well as one to whom the Massachusetts Medical Society is indebted for his persistent efforts to preserve that Association from all encroachment by pretenders.

Resolved, That we extend our sympathy to his widow and family connections in their bereavement, and that a copy of these resolutions be sent to the family, by the Secretary, and that they be placed upon the records of this Society, and published in the local papers, and in the Boston Medical and Surgical Journal.

\section{PlinY EaRLE.}

C. L. KNOWLTON.

\section{SOCIETY NOTICES.}

Suffolk District Medical Society. Obstetric and Gynocological Section. - There will be a meeting of this Section in the large hall of the Medical Library Association, 19 Boylston Place, on Wednesday evening, March 18th, at 7.45 o'elock. 'The following papers will be presented: Dr. John L. Sullivan, "Treatment of Abortion, with Cases." Dr. J. R. Chad- wick, "SeverfCases of Pregnancy and Labor complicated with Fibroids." Among those who will take part in the discussions are Drs. Sinclair, John Homans, Reynolds, Francis Minot, Boardman, Doe, Garland, Fifield, and J. W. Elliot.

JAMES R. CHADWICK, M.D., Chairman. ROBERT B. DIXON, M.D., Secretary.

Rhodf Island Medical Society.- A quarterly meeting of the Rhode Island Medical Society will be held at Lyceum Hall, 62 Westminster Street. Providence, at ten o'clock, A.M., on Thursday, March 19, 1885. Dr. G. D. Hersey will read a paper on "Tracheotomy, with special reference to after-treatment." Dr. R. F. Noyes will open a discussion on "Typhoid Fever occurring during Pregnancy."

Candidates for fellowship are requested to meet the Board of Censors in the Medical Library at ten o'clock, A.M., on Tuesday, the 17 th instant. $\quad$ G. D. Hersex, M.D., Secretary.

\section{AMERICAN MEDICAL ASSOCIATION.}

ARrangements have been made to run a special train of parlor cars from Boston to New Orleans and return without change, for the accommodation of physicians and their friends who desire to visit that city during the session of the Association. The train will leave the Boston and Albany depot on Friday, April 24th, at 3 P.M., Worcester at 4.20 P.M., Springfield at 6.15 P.M., Providence at 2 P.M., arriving in New Orleans, Monday, 27 th, at 9 A.M. Arrangements will be made in advance for meals en route.

The fare for the round trip will be: From Boston, $\$ 41.50$; from Worcester, $\$ 40.00$; from Providence, $\$ 41.50$; from Springfield $\$ 38$. As the number of tickets will be limited, it is requested that all who intend to go should communicate with Dr. W. E. Anthony, of Providence, R. I., who will furnish tickets and any further information that may be desired. In order that requisite accommodations may be provided, applications to join the party should be made before April 20 th.

\section{CORRECTION.}

Mr. Eorror, - Will you kindly allow me to correct an error in my report of the proceedings of the Obstetrical Society of Boston, which appeared in the JounNal of February $26 \mathrm{th}$, page 203?

In the discussion on Dr. E. J. Forster's paper on "Pelvic Abscess following Childbirth," Dr. Baker's remarks should read as follows: Dr. Baker said that the effusion was first aspirated to establish the diarnosis; then, using the aspirating needle as a director, Dr. Forster opened the abscess with a long, narrowbladed bistoury sufficiently to admit the finger. Yours truly,

C. M. Green.

\section{RESIGNATIONS.}

Dr. Frank W. Page, who has been resident physician at the Adams Nervine Asylum since the opening of that institution five years ago, has resigned, to engage in private practice.

Massachusetts General Hospital. - Dr. F. Gordon Morrill has resigned the position of physician to out-patients. 